\title{
Assessment of Metals Concentration in Water, Sediment and Macrophyte Plant Collected from Lake Hawassa, Ethiopia
}

Tigist Ashagre Amare*, Girma Tilahun Yimer and Kassaye Balkew Workagegn

Department of Biology, College of Natural and Computation Sciences Hawassa University, P.O. Box 5, Hawassa, Ethiopia

\begin{abstract}
This study was aimed to assess the concentration of metals $(\mathrm{Hg}, \mathrm{Cr}, \mathrm{Zn} \mathrm{Cd}$ and $\mathrm{Pb})$ in water, sediment, and $\mathrm{S}$. corymbosus macrophyte plant samples collected from six different sites $\left(\mathrm{S}_{1}\right.$ to $\left.\mathrm{S}_{6}\right)$ of Lake Hawassa. The results revealed that there was significant difference $(p<0.05)$ in metals concentration among different sampling sites as well as within the site. Generally, significantly higher values $(p<0.05)$ of metals concentration were recorded at sites $S_{2}, S_{4}$ and $S_{5}$, which received industrial effluents, urban wastes and agrochemicals respectively. and were the most contaminated sites. The concentration of metals both in sediment and macrophyte plant followed similar pattern, viz., $\mathrm{Zn}>\mathrm{Cr}>\mathrm{Pb}>\mathrm{Cd}>\mathrm{Hg}$, while the concentration of metals in water followed the order of $\mathrm{Zn}>\mathrm{Pb}>\mathrm{Cr}>\mathrm{Cd}>\mathrm{Hg}$. High to very high correlations were recorded within some metal pairs and with some physico-chemical parameters. - Although metals concentration in water and sediment of the lake are generally in non-polluted to moderately polluted range according to international standards based on numerical sediment quality guidelines (SQGs), almost all values at different sampling sites along the shoreline are much higher than the reference site as well as the background metals concentration of the lake. This is a clear indication that Lake Hawassa is exposed to different pollutants from all directions and the problem can easily go out of hand unless a special attention to be properly monitored for better protection of the lake and the surrounding catchment areas is given. as different human activities are increasing around the lake. Therefore, strategies to control point and non-point sources of all over the shorelines should be developed for better protection of the lake as well as the surrounding catchment areas.
\end{abstract}

Keywords: Lake Hawassa; metals; water; sediment; aquatic macrophyte; SQGs

\section{Introduction}

The problems of metal pollution are currently increasing in many Ethiopian Rift Valley Lakes. It is mainly associated with expansion of industrial activities and intensification of agricultural activities. Due to fast growing industries in and around Hawassa city, Lake Hawassa is one of the most exposing lakes to different sources of pollutant $[1,2]$. Under some environmental conditions, those pollutants including metals could accumulate and get biomagnified through food chain to toxic levels and eventually results in ecological damage [3]. The major factors to increase concentration of pollutants in Lake Hawassa include the Hawassa Textile Factory, Tabor Ceramic Products Share Company, Hawassa Millennium Soft Drink, City Municipality Abattoir, Hawassa ETAB Soap Factory, Flour Factories, Hawassa Referral Hospital and Floriculture Farms. Some of them dispose their solid and liquid wastes directly in to the lake or to shallow (Cheleleka) swamp, which is directly connected to the lake through Tikur Wuha River. Despite of intensive and extensive works that have been done on Lake Hawassa with regard to bacterioplankton [4], phytoplankton [5], zooplanktons [6], and fish [7], little information is documented about metal concentrations related to sediment, water and macrophytes of this lake. In addition, there is limited information on the potential mobility and simulation uptake of important metals form contaminated environments. Therefore, it is necessary to determine the concentration of metals in aquatic macrophytes, as well as in the growing media: water and sediment [8]. Consequently, information pertaining the state of metals in contaminated aquatic systems and their potential risk to aquatic organisms and other terrestrial organisms including human is of paramount importance to formulate and implement sound environment system in metal affected aquatic systems. Therefore, the main objective of this study was to assess the concentration level of selected metals in the water, sediment and aquatic macrophytes of Lake Hawassa.

\section{Materials and Methods}

\section{Description of study area and sampling sites}

Lake Hawassa is found in the middle of a series of rift valley lakes and located at $6^{\circ} 33^{\prime}-7^{\circ} 33^{\prime} \mathrm{N}$ latitude and $38^{\circ} 22^{\prime}-39^{\circ} 29^{\prime} \mathrm{E}$ longitude in the southern part of Ethiopia at a distance of $275 \mathrm{~km}$ south of Addis Ababa. The lake has one known small tributary namely, Tikur Wuha River that fed the lake from the northeast direction. There is no any known outflow from the lake. Different vegetation types that extend to the lake offshore cover the littoral area of the lake. The lake is also known for commercial fisheries, as it is inhabited by different fish species such as Tilapia, African catfish and Barbus sp. [6,7]. Based on the potential exposure of the lake to different source of agro-industrial and other source of pollutants, six representative sampling sites: (Site-1 $\left(\mathrm{S}_{1}\right)$ : Asama Ber, Site-2 $\left(\mathrm{S}_{2}\right)$ Tikur Wuha, Site-3 $\left(\mathrm{S}_{3}\right)$ Green Wood, Site-4 $\left(\mathrm{S}_{4}\right)$ Amora Gedel, Site-5 $\left(\mathrm{S}_{5}\right)$ Bete Mengist and Site-6 $\left(\mathrm{S}_{6}\right)$ Kuyuwata: reference site) were selected (Figure 1).

\section{Water, sediment and macrophyte sampling}

Water samples were collected from six selected sites from different locations of each site of the lake at about $10 \mathrm{~cm}$ depth of the water

*Corresponding author: Tigist Ashagre Amare Department of Biology, College of Natural and Computation Sciences Hawassa University, P.O. Box 5, Hawassa, Ethiopia, Tel: +251911093254; E-mail:tigistashagre@yahoo.com

Received September 17, 2014; Accepted October 27, 2014; Published October 31,2014

Citation: Amare TA, Yimer GT, Workagegn KB (2014) Assessment of Metals Concentration in Water, Sediment and Macrophyte plant Collected from Lake Hawassa, Ethiopia. J Environ Anal Toxicol 5: 247. doi: 10.4172/2161 0525.1000247

Copyright: (c) 2014 Amare TA, et al.. This is an open-access article distributed under the terms of the Creative Commons Attribution License, which permits unrestricted use, distribution, and reproduction in any medium, provided the original author and source are credited. 
column (Figure 1). To remove metal contaminants, the sampling plastic bottles were washed with $10 \% \mathrm{HNO}_{3}$ and were rinsed thoroughly with distilled water. Soon after collection, all the samples were acidified by adding a few drops of $10 \% \mathrm{HNO}_{3}$. Similarly, sediment samples were collected from different locations of each site using Ekman grab and were placed in polyethylene bags. The macrophyte plant samples were also collected from different location of each site for all study sites. The plant samples were washed with lake water and then with 5\% EDTA solution and were rinsed with distilled water before placed in plastic bags. Later, all the samples were packed and labeled carefully and then placed at $4^{\circ} \mathrm{C}$ $[9,10]$. Finally, the samples were transported to Ethiopian Environmental Protection Authority EPA laboratory in Addis Ababa for analysis.

\section{Sample digestion}

At EPA laboratory, all the sediment and the plant samples were digested separately using aqua-regia and dry-ash methods respectively. In aqua-regia method, $1 \mathrm{~g}$ of sediment sample from each sample was weighed and was soaked in aqua-regia solution that contains $7.5 \mathrm{~mL}$ of $37 \% \mathrm{HCl}$ and $2.5 \mathrm{~mL}$ of $68 \% \mathrm{HNO}_{3}$ with a ratio of 3:1. The samples were digested for two hours at $105^{\circ} \mathrm{C}$ and were cooled. The samples were then diluted with $20 \mathrm{~mL}$ of $2 \%$ nitric acid and were filtered by using $0.45 \mu \mathrm{m}$ filter paper. Similarly, for dry-ash method, $1 \mathrm{~g}$ of plant sample from each sample was placed in labeled crucible glass separately. All the crucible glasses were then placed in a muffle furnace and were heated

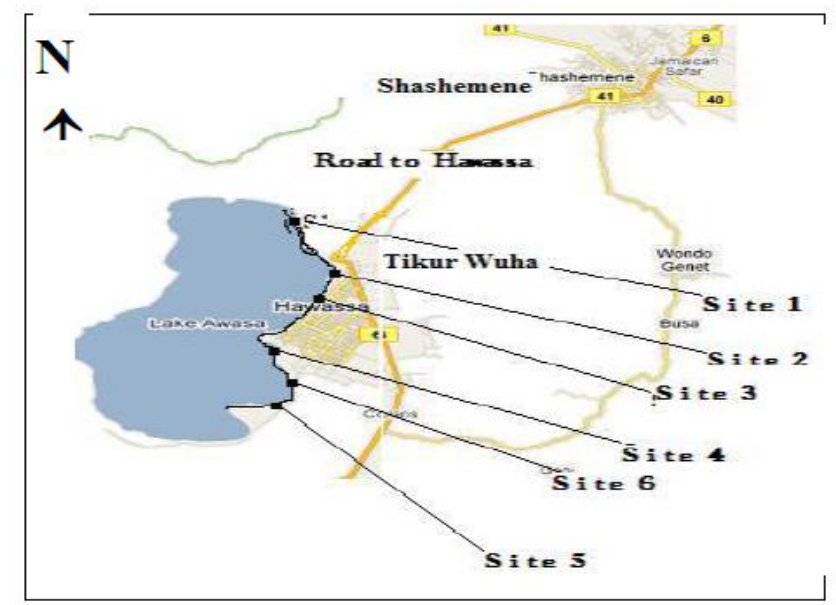

Figure 1: Location of the six study sites on Lake Hawassa, (source: www. panoramio.com) to $450^{\circ} \mathrm{C}$ until the samples become a white ash. The white ash of the samples was then cooled overnight. To make solutions for all samples 5 $\mathrm{mL}$ of $6 \mathrm{~mol} \mathrm{~L}^{-1}$ of $\mathrm{HNO}_{3}$ was added to the white ash of the samples and then place in the fume hood. Meanwhile, step by step, $5 \mathrm{~mL}$ of $3 \mathrm{~mol}$ $\mathrm{L}^{-1}$ and then $1 \mathrm{~mol} \mathrm{~L}^{-1}$ of $\mathrm{HNO}_{3}$ was added to the solution. The plant samples were then heated in hot plate oven for 30 minutes. The samples were diluted with distilled water to get a total of $50 \mathrm{ml}$ sample solution and were filtered using $0.45 \mu \mathrm{m}$ filter paper [9-11]. Then, all the samples were ready for analysis.

\section{Data analyses}

In this study, some water characterization was performed for selected parameters. Total dissolved substances (TDS), temperature, concentration of dissolved oxygen (DO), hydrogen ion concentration $(\mathrm{pH})$ and electrical conductivity (EC) of lake water were measured using Hydrolab meter, Model "Multi 340I/SET. Organic matter and pH of sediment samples were also analyzed at Addis Ababa EPA laboratory. Metal concentrations such as mercury $(\mathrm{Hg})$, chromium $(\mathrm{Cr})$, zinc $(\mathrm{Zn})$, cadmium $(\mathrm{Cd})$ and lead $(\mathrm{Pb})$ were analyzed for all the three types of samples using Graphite Furnace Atomic Absorption Spectrometry.

\section{Statistical analyses}

Statistical analysis was carried out using SPSS Version 13 computer package. One way ANOVA t test was applied to compare the mean concentration of metals at different Sites at $\mathrm{p} \leq 0.05$. Pearson correlation coefficients were determined to examine the relationship between the levels of elements in water, sediment and aquatic macrophyte plant samples.

\section{Results}

\section{Physico-chemical parameters from in-situ measurements}

Individual characteristics of some physico-chemical parameters of the lake water and sediment samples are presented in Table 1. With a few exceptions, values recorded at $\mathrm{S}_{1}$ to $\mathrm{S}_{5}$ were generally higher than at $\mathrm{S}_{6}$. Statistical analysis showed that the mean differences of the physicochemical parameters recorded at different sampling sites of the lake water were significantly $(\mathrm{P}<0.05)$ different among sites. Sediment samples analysis revealed that the $\mathrm{pH}$ and $\mathrm{OM}$ values were significantly different. The total $\mathrm{pH}$ mean value of the sediment was generally lower than the $\mathrm{pH}$ value of lake water. OM in lake sediment at $\mathrm{S}_{4}$ and $\mathrm{S}_{2}$ were significantly higher $(\mathrm{P}<0.05)$ and more than threefold of the rest of the sites.

Metals concentration in water, sediments and macrophyte plant

Table 1: Mean values of different physico-chemical parameters \pm standard deviation $(S D)$ of in-situ measurement of lake water, laboratory analysis of sediment samples of Lake Hawassa and standard values for drinking water.

\begin{tabular}{|c|c|c|c|c|c|c|c|}
\hline \multirow{2}{*}{$\begin{array}{l}\text { Physico-chemical } \\
\text { Parameters }\end{array}$} & \multicolumn{7}{|c|}{ Sampling sites } \\
\hline & $\mathrm{S}_{1}$ & $\mathrm{~S}_{2}$ & $\mathbf{S}_{3}$ & $\mathbf{S}_{4}$ & $\mathrm{~S}_{5}$ & $\mathrm{~S}_{6}$ & $\begin{array}{l}\text { Drinking water } \\
\text { Standard [12] }\end{array}$ \\
\hline \multicolumn{8}{|l|}{ Lake water } \\
\hline $\mathrm{pH}$ & $7.7 \pm 0.12 a$ & $9.52 \pm \_0.19 d$ & $9.17 \pm 0.08 \mathrm{~cd}$ & $8.86 \pm 0.02 b c$ & $9.14 \pm 0.02 \mathrm{~cd}$ & $8.5 \pm 0.06 b$ & $6.5-8.5$ \\
\hline $\mathrm{DO}\left(\mathrm{mg} \mathrm{L}^{-1}\right)$ & $7.6 \pm 0.12 d$ & $6.6 \pm 0.12 b c$ & $6.2 \pm 0.12 \mathrm{ab}$ & $6.9 \pm \_0.05 c$ & $5.7 \pm 0.17 a$ & $6.1 \pm 0.15 \mathrm{ba}$ & $4.5-7.5$ \\
\hline Temperature $\left({ }^{\circ} \mathrm{C}\right)$ & $22.5 \pm 0.41 a$ & $26.7 \pm 0.29 c$ & $27.4 \pm 0.23 c$ & $27 \pm 0.29 c$ & $29 \pm 0.12 d$ & $25 \pm 0.12 b$ & \\
\hline TDS $\left(\mathrm{mg} \mathrm{L}^{-1}\right)$ & $562 \pm 1.73 c$ & $681 \pm 0.58 \mathrm{e}$ & $507 \pm 2.31 a$ & $516 \pm 0.58 b$ & $603 \pm 1.73 d$ & $521 \pm 2.31 b$ & 1000 \\
\hline $\mathrm{EC}\left(\mu \mathrm{S} / \mathrm{cm} \mathrm{K} \mathrm{K}_{20}\right)$ & $603 \pm 1.73 a$ & $895 \pm 2.89 f$ & $770 \pm 1.16 c$ & $785 \pm 2.89 d$ & $845 \pm 2.89 \mathrm{e}$ & $642 \pm 1.16 b$ & 1500 \\
\hline \multicolumn{8}{|l|}{ Sediment sample } \\
\hline $\mathrm{pH}$ & $6.64 \pm 0.08 a$ & $8.2 \pm 0.10 c$ & $7.95 \pm 0.10 c$ & $7.41 \pm 0.15 b$ & $8.19 \pm 0.16 c$ & $7.21 \pm 0.01 b$ & \\
\hline $\mathrm{OM}(\%)$ & $4.3 \pm 0.09 b$ & $11.77 \pm 0.26 c$ & $2.96 \pm 0.15 a$ & $14.46 \pm 0.26 d$ & $3.30 \pm 0.02 a$ & $3.11 \pm 0.01 a$ & \\
\hline
\end{tabular}

*Values with different letters showed significant differences $(P<0.05$, ANOVA), letter "a" indicates the smallest value for a given physico-chemical parameters (DO-dissolved oxygen concentration,TDS-total dissolved substances, EC-electrical conductivity ( $\mu \mathrm{S} / \mathrm{cm} \mathrm{K20} \mathrm{is} \mu \mathrm{S} / \mathrm{cm}$ at $\left.20^{\circ} \mathrm{C}\right)$, pH hydrogen ion concentration and OM-organicmatter. 
Citation: Amare TA, Yimer GT, Workagegn KB (2014) Assessment of Metals Concentration in Water, Sediment and Macrophyte Plant Collected from Lake Hawassa, Ethiopia. J Environ Anal Toxicol 4: 247. doi: 10.4172/2161-0525.1000247

Page 3 of 7

The analytical results for concentrations of $\mathrm{Hg}, \mathrm{Cr}, \mathrm{Zn}, \mathrm{Cd}$ and $\mathrm{Pb}$ were determined in water, sediment and plant samples collected from the six sites are presented in Tables 2-4 respectively. Among all metals in water samples, the $\mathrm{Pb}$ was the only metal detected at all sites, while $\mathrm{Hg}$ in sites $\mathrm{S}_{1}, \mathrm{~S}_{2}$ and $\mathrm{S}_{4}, \mathrm{Cr}$ in site $\mathrm{S}_{2}, \mathrm{Zn}$ in sites $\mathrm{S}_{2}$ and $\mathrm{S}_{3}$ and $\mathrm{Cd}$ in sites $\mathrm{S}_{2}$ and $\mathrm{S}_{6}$. $\mathrm{S}_{2}$ was the only site in which all the analyzed metals were detected.

Similarly, the results showed that the mean difference of metals concentration in sediment samples at all study sites were significantly different $(\mathrm{P}<0.05)$. Without any exception, the lowest concentrations of metals were found at $\mathrm{S}_{6}$ (Table 2).

Similarly, the results showed that there was a significant difference $(\mathrm{P}<0.05)$ of most metals concentration in plant growing at different sites of the lake. The minima for the concentration of these metals were recorded at $\mathrm{S}_{6}$ (Table 4 ).

\section{Correlation matrix for intra-and inter-physico-chemical}

Correlation matrix for the data was evaluated to determine the level of intra- and inter-physico-chemical correlation and the values was determined. For most parameter pairs, the results showed that there were high positive to negative correlation and even no correlation for some pairs of parameters. The results revealed that the values of the parameters in the different samples were significantly $(\mathrm{p}<0.05)$ correlated. The products of the correlation coefficient $[\mathrm{r}]$ were evaluated as suggested in Norusis [16] as 0-0.3: No correlation; 0.3-0.5: Low correlation; 0.5-0.7: Medium correlation; 0.7-0.9: High correlation; 0.91.0: Very high correlation.

\section{Discussion}

\section{Physicochemical characterstics}

The present results for $\mathrm{pH}$ value of the water and sediment samples collected from Lake Hawassa showed a considerable variation among different study sites. The highest $\mathrm{pH}$ values $(9.52 \pm 0.19)$ for water sample and for sediment $(8.2 \pm 0.16)$ were recorded at $S_{2}$, while the lowest $\mathrm{pH}$ value for water $(7.7 \pm 0.12)$ and sediment $(6.64 \pm 0.08)$ samples were registered at $\mathrm{S}_{1}$ Except $\mathrm{S}_{1} \mathrm{pH}$ values of lake water from $\mathrm{S}_{2}$ to $S_{5}$ were above 8.5 , and these values fell out of the desirable range of $\mathrm{pH}(6.5-8.5)$ for drinking water set by WHO, [12] indicating that there is human influences in the lake area. In all cases, the $\mathrm{pH}$ values of both water and sediment samples implied that the condition of the lake is alkaline. The responsible factors for the alkaline value of the $\mathrm{pH}$ might be agro-industrial activities found in the surrounding areas of the lake. Karpisack et al. [17] suggest that alkalinity of the lake water increases with increasing contaminants from industries and agricultural

Table 2: Mean value of metal concentration $\pm \mathrm{SD}$ in $\mu \mathrm{g} \mathrm{L}^{-1}$ of lake water values in parentheses (), square brackets [] \& brace \{\} indicate maximum permissible levels (MPL)

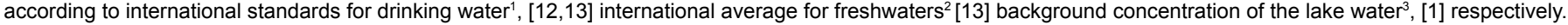

\begin{tabular}{|c|c|c|c|c|c|}
\hline \multirow{2}{*}{ Sites } & \multicolumn{5}{|c|}{ Chemical Parameters } \\
\hline & $\mathrm{Hg}(1)[0.1]\{N D\}$ & $\operatorname{Cr}(50)[11.4]\{5.7\}$ & $\operatorname{Zn}(5000)[30]\{1.6\}$ & $\mathrm{Cd}(5)[0.017]\{N D\}$ & $\mathrm{Pb}(10)[1.7]\{\mathrm{ND}\}$ \\
\hline $\mathrm{S}_{1}$ & $0.116 \pm 0.002 b$ & ND & ND & ND & $49.47 \pm 0.37 f^{\star}$ \\
\hline $\mathrm{S}_{2}$ & $0.117 \pm 0.006 b$ & $6.48 \pm 0.31$ & $0.219 \pm 0.58 b$ & $0.094 \pm 0.003 a$ & $6.111 \pm 0.12 \mathrm{~d}$ \\
\hline $\mathrm{S}_{3}$ & ND & ND & $0.044 \pm 0.12 a$ & ND & $9.705 \pm 0.05 \mathrm{e}$ \\
\hline $\mathrm{S}_{4}$ & $0.025 \pm 0.0004 a$ & ND & ND & ND & $5.22 \pm 0.028 c$ \\
\hline $\mathrm{S}_{5}$ & ND & ND & ND & ND & $4.044 \pm 0.025 b$ \\
\hline $\mathrm{S}_{6}$ & ND & ND & ND & $0.1 \pm 0.00 \mathrm{~b}$ & $0.79 \pm 0.0001 a$ \\
\hline
\end{tabular}

*Values with different letters showed significant differences $(P<0.05$, ANOVA), letter "a" indicates the smallest value for a given physico-chemical parameter. Values with *and bold indicate those above MPL in drinking water and the background concentration, respectively, ND= not detected

Table 3: Mean value of metal concentration \pm SE in $\mathrm{mg} \mathrm{kg-l} \mathrm{of} \mathrm{dry} \mathrm{weight} \mathrm{of} \mathrm{sediment} \mathrm{samples} \mathrm{collected} \mathrm{from} \mathrm{Lake} \mathrm{Hawassa,} \mathrm{Values} \mathrm{in} \mathrm{parentheses} \mathrm{()} \mathrm{and} \mathrm{square} \mathrm{bracket}$ [] indicate maximum acceptable levels (MAL) according to international standards for soil/sediment, anon-polluted, bmoderately polluted and cheavily polluted on the basis of numerical sediment quality guidelines (SQGs) $[13,14]$.

\begin{tabular}{|c|c|c|c|c|c|}
\hline \multirow{2}{*}{ Sites } & \multicolumn{4}{|c|}{ Chemical Parameters } & \multirow[b]{2}{*}{$\mathrm{Pb}(0.2-2.0)\left[<40^{\mathrm{a}}, 40-60^{\mathrm{b}},>60^{\mathrm{c}}\right]$} \\
\hline & $\mathrm{Hg}(0.05)$ & $\operatorname{Cr}(0.1-1),\left[<25^{\mathrm{a}}, 25-75^{\mathrm{b}},>75^{\mathrm{c}}\right]$ & $\mathrm{Zn}(1-5),\left[<90^{\mathrm{a}}, 90-200^{\mathrm{b}},>200^{\mathrm{c}}\right]$ & $\mathrm{Cd}(0.01-0.05)$ & \\
\hline $\mathrm{S}_{1}$ & $0.00052 \pm 0.00009 a$ & $2.05 \pm 0.02 a$ & $32.13 \pm 06 b$ & $0.027 \pm 0.0018 a$ & $0.71 \pm 0.05 b$ \\
\hline $\mathrm{S}_{2}$ & $0.00068 \pm 0.00003 c$ & $9.69 \pm 0.18 b$ & $61.6 \pm 0.35 c$ & $0.032 \pm 0.009 b$ & $0.75 \pm 0.009 a$ \\
\hline $\mathrm{S}_{3}$ & $0.00066 \pm 0.00004 a$ & $5.69 \pm 0.13 e$ & $58.89 \pm 0.36 c$ & $0.021 \pm 0.0005 a$ & $1.44 \pm 0.03 c$ \\
\hline $\mathrm{S}_{4}$ & $0.00017 \pm 0.00004 b$ & $8.10 \pm 0.35 d$ & $107.5 \pm 4.45 \mathrm{e}^{*}$ & $0.035 \pm 0.0035 c$ & $1.73 \pm 0.04 d$ \\
\hline $\mathrm{S}_{5}$ & $0.00054 \pm 0.00003 a$ & $6.86 \pm 0.1 c$ & $71.95 \pm 06 d$ & $0.018 \pm 0.0007 a$ & $1.32 \pm 0.05 c$ \\
\hline $\mathrm{S}_{6}$ & $0.00011 \pm 0.00006 a$ & $1.56 \pm 0.02 a$ & $11.4 \pm 0.06 a$ & $0.012 \pm 0.0001 a$ & $0.56 \pm 0.03 a$ \\
\hline
\end{tabular}

*Values with different letters showed significant differences $(P<0.05$, ANOVA), letter "a" indicates the smallest value for a given physico-chemical parameter. Values with bold and * indicate those above MAL in sediment and polluted sediment[13,14].

Table 4: Mean value of metal concentration $\pm \mathrm{SD}$ in $\mathrm{mg} \mathrm{kg-1}$ of dry weight of in $\mathrm{S}$. corymbosus growing around the lake, value in parentheses () is critical range of metals in plant species.

\begin{tabular}{|c|c|c|c|c|c|}
\hline \multirow{2}{*}{ Site } & \multicolumn{5}{|c|}{ Chemical parameters } \\
\hline & $\mathrm{Hg}(0.00015-0.00071)$ & $\mathrm{Cr}(0.081-0.370)$ & $\operatorname{Zn}(0.1-0.4)$ & $\mathrm{Cd}(0.01-0.03)$ & $\mathrm{Pb}(0.03-0.3)$ \\
\hline $\mathrm{S}_{1}$ & $0.00017 \pm 0.000006 b$ & $8.19 \pm 0.08 c$ & $21.46 \pm 0.32 c$ & $0.009 \pm 0.0005 b$ & $0.65 \pm 0.035 c$ \\
\hline $\mathrm{S}_{2}$ & $0.00021 \pm 0.00001 \mathrm{c}$ & $12.15 \pm 0.24 d$ & $17.28 \pm 0.006 b$ & $0.013 \pm 0.00002 d$ & $0.484 \pm 0.01 b$ \\
\hline $\mathrm{S}_{3}$ & $0.00011 \pm 0.000006 a$ & $8.56 \pm 0.26 c$ & $22.04 \pm 0.39 d$ & $0.012 \pm 0.0006 \mathrm{~cd}$ & $0.67 \pm 0.023 \mathrm{~cd}$ \\
\hline $\mathrm{S}_{4}$ & $0.00012 \pm 0.000006 a$ & $5.98 \pm 0.11 b$ & $29.4 \pm 0.39 e$ & $0.01 \pm 0.001 b c$ & $0.51 \pm 0.012 b$ \\
\hline $\mathrm{S}_{5}$ & $0.0007 \pm 0.00001 d$ & $6.25 \pm 0.04 b$ & $20.92 \pm 0.07 d$ & $0.0088 \pm 0.0004 b$ & $0.76 \pm 0.023 d$ \\
\hline $\mathrm{S}_{6}$ & $0.0001 \pm 0.00000 a$ & $1.29 \pm 0.03 a$ & $1.417 \pm 0.04 a$ & $0.0051 \pm 0.0001 a$ & $0.147 \pm 0.002 a$ \\
\hline
\end{tabular}

*Values with different letters showed significant differences $(P<0.05)$, letter "a" indicates the smallest value for a given physicochemical parameters $[8,15]$. 
activities. Therefore, the higher $\mathrm{pH}$ levels at $\mathrm{S}_{2}$ and $\mathrm{S}_{5}$ could be due to the impact of Tikur Wuha River that contains different contaminants from different sources of pollutants and intensive agricultural activities respectively. Furthermore, the higher $\mathrm{pH}$ value for $\mathrm{S}_{3}$ might be related to the municipal waste produced by Hawassa city that is directly or indirectly released to this site. In line with our result, Zerihun [2] reported that the $\mathrm{pH}$ value of Lake Hawassa and its feeders was highly alkaline particularly around the mouth of Tikur Wuha River.

The results of this study also revealed that there was a great variation in DO concentration at different locations of the lake. The highest DO concentration was recorded at $S_{1}$, while the lowest DO concentration registered at $S_{5}$. The reason for lower DO concentration is due to the presence of high amount of OM (11.77\%) at this site, which has high oxygen-demand for bacterial decomposition $[18,19]$. In general, the recorded level of DO concentration in the lake water ranged between $5.7 \pm 0.17$ to $7.6 \pm 0.12 \mathrm{mg} \mathrm{L}^{-1}$ and fell within the range values reported by WHO [12]. Generally the DO concentration records at all selected sites were within the guideline values cited by USEPA [10] for the protection of aquatic life [for warm water biota: early life stages $=6$ $\mathrm{mg} \mathrm{L}^{-1}$, other life stages $\left.=5.5 \mathrm{mg} \mathrm{L}^{-1}\right]$. The EC values were also ranged from $603 \pm 1.73$ to $895 \pm 2.89 \mu \mathrm{S} / \mathrm{cm} \mathrm{K}_{20}$ during the investigation period. The maximum values $895 \pm 2.89 \mu \mathrm{S} / \mathrm{cm} \mathrm{K}_{20}$ was recorded at $\mathrm{S}_{2}$ which may be receiving the agro-industrial wastes from the surrounding environments via Tikur Wuha River as explained by Seyoum et al. [20]. In addition, the higher electrical conductivity observed at $S_{2}$ could be attributed to the relatively low DO concentration and revealed high negative correlation to each other (temp/DO: $r=-0.771$ ). This result is in accordance with the works of Phiri et al. [21] and Okafor [22] who reported that high $\mathrm{EC}$ contribute for reduction of $\mathrm{DO}$ concentration in the given water bodies.

Similarly, TDS showed great variation and ranged from $507 \pm$ 2.31 at $\mathrm{S}_{3}$ to $681 \pm 0.58$ at $\mathrm{S}_{2} \mathrm{mg} \mathrm{L}^{-1}$. These values were far below the WHO [12] guideline value prescribed for drinking water $\left(1000 \mathrm{mg} \mathrm{L}^{-1}\right)$. In general, the present results clearly indicated that there was interphysico-chemical association with significant correlation between them in aquatic system. The results clearly indicated that $\mathrm{OM}, \mathrm{pH}$ and DO concentration had significantly correlated $(\mathrm{OM} / \mathrm{pH}: \mathrm{r}=0.589$ and OM/DO: $\mathrm{r}=-0.530$ and were consistent with the work of Kar et al. [23]. There are high correlation between most of the concentration of metals analyzed in this study and the physico-chemical parameters such as $\mathrm{pH}$, temperature, EC, DO and OM.

\section{Metals concentrations in water, sediments and s. corymbosus macrophyte}

\section{Metal concentrations in water}

The analytical result of this study showed that the mean values of metals concentrations in lake water were significantly different among sampling sites $(\mathrm{P}<0.05)$. Most of the metals in water samples taken from different sites were not detected. However, $\mathrm{S}_{2}$ was the only site in which all the analyzed metals were detected. Likewise, the lead was the only metal detected at all sites and had the highest with a mean value of 0.013 $\pm 0.001 \mathrm{mg} \mathrm{L}^{-1}$, while the lowest total metal concentration was $\mathrm{Hg}$ with a mean value of $0.00004 \pm 0.000002 \mathrm{mg} \mathrm{L}^{-1}$. This result agrees with the work of Teresa and Neff [15]. The author reported that among several metals analyzed in fresh water body, the lowest metal concentration was Hg. It was even not detected in some of the experimental sites. Moreover, our result agrees with the work of Zinabu [1] who reported that $\mathrm{Hg}$ and other metals were not detected in this lake. Moreover, with the exception of $\mathrm{Pb}$ at $\mathrm{S}_{1}$, all the detected metals concentrations were below the maximum permissible levels (MPL) for drinking water $[12,13]$. Even though the values were below the acceptable ranges for drinking water, concentration of metals found in this study was higher than the background concentration metal level indicated by Zinabu [1]. Furthermore, with few exceptions (i.e. $\mathrm{Zn}$ and $\mathrm{Cr}$ ), all the detected metal concentrations were above the international mean value of metal concentration found in freshwater [12].

Inter-site comparisons showed that the lowest $\mathrm{Hg}$ and $\mathrm{Cd}$ concentration were recorded at $\mathrm{S}_{2}$, while the highest concentrations of $\mathrm{Zn}, \mathrm{Cr}$ and $\mathrm{Pb}$ were detected. The existence of two or more metals in a given location might be due to the chemical affinity between them [24]. In accordance with our result pairs of $\mathrm{Zn} / \mathrm{Cd}(\mathrm{r}=0.597)$ had medium positive correlation implying that they have similar sources or phenomenon [23]. Moreover, higher metal concentration at those sites might be related to the higher correlation between those metals and physico-chemical parameters (e.g. pairs of $\mathrm{Hg} / \mathrm{DO}, \mathrm{Hg} / \mathrm{TDS}, \mathrm{Cr} /$ $\mathrm{OM}, \mathrm{Zn} / \mathrm{Tem}, \mathrm{Zn} / \mathrm{TDS}, \mathrm{Zn} / \mathrm{OM}, \mathrm{Cd} / \mathrm{pH})$. The higher values of those physico-chemical parameters contribute for higher concentration of metals as suggested by Igbinosa and Okoh [18] and Okafor and Opuene [22]. This implies that there are potential sources of pollutant to the lake from various directions particularly from the northern side of the lake. Therefore, agro industrial activities around $S_{1}$ and $S_{2}$ might be the sources of pollutant as compare to other sites.

\section{Metals concentrations in sediment}

The analysis of metals in sediment is used for detection of pollutants that may be either absent or in low concentrations in the water column $[25,26]$. The concentration of metals from the overlying water to the sediment is dependent on a number of external environmental factors such as $\mathrm{pH}, \mathrm{EC}$, the ionic strength of the compound, anthropogenic input, the type and concentration of organic and inorganic ligands and the available surface area for adsorption caused by variation in grain size distribution [27].

Determination of metal elements in lake sediment during drought period revealed that all the analyzed heavy metals were present. In view of the concentration, levels of those studied metals, the highest values were for $\mathrm{Zn}$ and $\mathrm{Cr}$ at all sites. This may be attributed to the fact that $\mathrm{Zn}$ and $\mathrm{Cr}$ are the most abundant elements in the earth's crust as studied on Nile sediment [28]. The concentration levels of $\mathrm{Hg}$, Cd and $\mathrm{Pb}$ were low as compared to $\mathrm{Zn}$ and $\mathrm{Cr}$. They were found above the background concentration of the same lake [1] with a descending order of $\mathrm{Zn}>\mathrm{Cr}>\mathrm{Pb}>\mathrm{Cd}>\mathrm{Hg}$. The above sequence agrees with the findings of Siegel et al. [29] and Ramdan [30] in Lake Manzala, Egypt.

Metals concentrations of $\mathrm{Zn}, \mathrm{Cr}, \mathrm{Cr}$ and $\mathrm{Pb}$ from Lake Hawassa sediment as compared to the probable-effects-level (PEL) guidelines for toxic biological effects established and sediment-quality guidelines by USEPA [31], the present results revealed that metals concentration of sediment showed higher than the level of those elements set by the guidelines. Moreover, metals concentrations in the sediment including mercury exceeded the maximum acceptable levels cited by Frances [13]. However, according to MacDonald et al. [14] and Harikumar et al. [32] Lake Hawassa sediment was moderately polluted.

Correlation coefficient " $r$ " is some of the most important statistical tests to evaluate the strength or weakness relationships among physicchemical parameters as well as metal concentrations determined in this study. The results from statistical analysis revealed that water temperature, $\mathrm{pH}$ and EC showed strong associations among different physico-chemical parameters including heavy metal concentration. 
These showed that the important role of water temperature, EC and $\mathrm{pH}$ in the concentration of metals in aquatic ecosystem. These results coincide with the findings of Abdo [33] on Ismailia Canal, Egypt and Abdel-Satar [28] on Manzalah Lake, Egypt.

The positive correlation coefficient " $\mathrm{r}$ " between pairs for $\mathrm{Cr} / \mathrm{Zn}$, $\mathrm{Zn} / \mathrm{Pb}, \mathrm{Hg} / \mathrm{Cr}, \mathrm{Zn} / \mathrm{Cd}, \mathrm{Cr} / \mathrm{Cd}, \mathrm{Hg} / \mathrm{Cd}, \mathrm{Cd} / \mathrm{OM}, \mathrm{Cr} / \mathrm{pH}, \mathrm{Hg} / \mathrm{TDS}, \mathrm{Zn} /$ EC, $\mathrm{Pb} / \mathrm{EC}, \mathrm{Cr} / \mathrm{OM}$, Cr/Temp, Zn/OM, Hg/OM, Cr/EC, Hg/pH, Zn/ Temp and Cr/TDS represented the direct relationship between those parameters. Similarly, negative correlation coefficient "r" between elemental pairs of $\mathrm{Hg} / \mathrm{pH}, \mathrm{Cd} / \mathrm{pH}$ and $\mathrm{OM} / \mathrm{DO}$ represented the inverse relationship between those parameters which were consistent with the works of Kar et al. [23] and Nirmal et al. [24]. Generally, most of the physico-chemical parameters had higher correlation coefficient and can contribute for higher concentration of metals in aquatic ecosystems which is inconsistence with the works of Igbinosa and Okoh [18], Okafor and Opuene [22], and Kar et al. [23].

Inter-sites comparison showed that metals concentration varies from site to site so that the highest mean concentration of $\mathrm{Zn}, \mathrm{Cd}$ and $\mathrm{Pb}$ was recorded at $\mathrm{S}_{4}$ whereas the highest $\mathrm{Hg}$ and $\mathrm{Cr}$ concentration was recorded at $\mathrm{S}_{2}$. In all cases, the lowest metal concentration was observed at reference site $\left(\mathrm{S}_{6}\right)$. The highest concentration of total metals was generally recorded at the northern sites of the lake than the southeast sites of the lake which agrees with the work of Zinabu [1] in which high concentration of metals was recorded at around Tikur Wuha River. Site variation in metal concentration in this study is probably due to variation of organic matter content, $\mathrm{EC}$ and $\mathrm{pH}$ of the different sites as mentioned by Freedman [34]. This is because variations in physicochemical values at different sites contribute for the variation of metal concentration. In line with our results, Igbinosa and Okoh [18] and Sekabira et al. [35] reported that the concentration of metals in aquatic ecosystems are highly correlated with physico-chemical parameters as mentioned earlier by different authors. Agrochemical substances that runoff to those sites can cause variation in metal concentration. In accordance with this result, Nabizadeh et al. [36] reported that different runoff could have varieties of contaminants with different concentration and thus, contribute to increase metal concentration of the receiving water bodies.

\section{Metal concentration in aquatic macrophyte}

The analysis of metals in some macrophytes permitted to the detection of pollutants that may be either absent or in low concentrations in the water column or low concentration in sediment $[17,24,37]$. The accumulation of metals from the overlying water and sediment to the macrophyte plant is also dependent on a number of external environmental factors such a $\mathrm{pH}, \mathrm{EC}$, the ionic strength, anthropogenic input, the type and concentration of organic and inorganic ligands and the available surface area for adsorption caused by variation in grain size distribution [27]. In S. corymbosus the mean values of concentration of metals were significantly $(\mathrm{p}<0.05)$ different among sites. In this plant, the mean value of $\mathrm{Zn}$ concentration was the highest, followed by $\mathrm{Cr}$. This result implied that $\mathrm{Zn}$ and $\mathrm{Cr}$ were the most contaminant metals almost at all study sites. Moreover, the plant has higher uptake for those metals from the sediment in which they are growing. The lowest total metal concentration in plant samples was being $\mathrm{Hg}$. The general order of metal concentration in S. corymbosus was $\mathrm{Zn}>\mathrm{Cr}>\mathrm{Pb}>\mathrm{Cd}>\mathrm{Hg}$. This sequence agrees with the findings of Nirmal et al. [24], Siegel et al. [29], Ramdan [30] for different aquatic macrophyte plant species. The concentration of metals also varies at different studying sites. Intersite comparison showed that the highest $\mathrm{Hg}$ and $\mathrm{Pb}$ concentration was recorded at $\mathrm{S}_{5}$ followed by $\mathrm{S}_{2}$ for $\mathrm{Hg}$ and $\mathrm{S}_{3}$ for $\mathrm{Pb}$. The concentration of $\mathrm{Hg}$ at sites $\mathrm{S}_{3}$ and $\mathrm{S}_{4}$ had more or less similar. In case of $\mathrm{Zn}$ and $\mathrm{Cd}$, the highest concentration was registered at sites $S_{4}$ and $S_{2}$, respectively. Furthermore, $\mathrm{Zn}$ concentration at sites $\mathrm{S}_{3}$ and $\mathrm{S}_{5}$ was more or less similar. In all cases, the lowest metal concentration in this aquatic plant was recorded at reference site $\left(\mathrm{S}_{6}\right)$. Moreover, correlation of metals from very high to medium within metals and with physicochemical parameters suggests that some physico-chemical parameters may contribute for high concentration of specific types of metals at a particular site. For instance, the highest metal concentrations at site $S_{2}$ are might be due to the impact of different physic-chemical parameters.

The correlation for elemental pair such as $\mathrm{Hg} / \mathrm{Pb}, \mathrm{Zn} / \mathrm{Cd}$ and $\mathrm{Zn} /$ $\mathrm{Pb}$ in this study was consistent with the works of Kar et al. [23] and Nirmal et al. [24] and metal-physico-chemical pairs such as Cr/TDS and $\mathrm{Zn} / \mathrm{EC}$ were also consistent to the work of Sekabira et al. [35]. Particularly, the correlation of $\mathrm{Zn}$ with $\mathrm{Pb}$ and $\mathrm{Cd}$ in this study was agreed with the work of Okafor and Opuene[22]. The result confirmed that correlations between physico-chemical parameters contribute for high or low concentration of metals in a given medium.

\section{Comparison of metals concentration in water, sediment and macrophyte}

Sediment can act as both sink and source of contaminants, whereby long-term input of contaminants can lead to sedimental concentrations that can exceed to increase concentration in water $[18,38,39]$. However, the process of phytoremediation is the most important biotic factor used in outlining the program of macrophytic role in purification of contaminated sediment and water of aquatic ecosystems [17]. Moreover, aquatic plants can be used as bioindicator of metal pollution in the lake since metals present in water and sediment are slowly accumulated by aquatic plants and thereby concentrated in the plant tissues. The result showed that total concentration of metals found in water was lower than those found in lake sediment and macrophyte plants. Generally, the total concentration of metals in Lake Hawassa followed the order of sediment $>$ macrophyte $>$ water which agrees with the work of Nirmal et al. [24]. Similarly, Lovett-Doust et al. [40] reported that the accumulation level of pollutants in aquatic ecosystems is higher in sediments than in plants if the receiving water body is exposed to different source of contaminants. The sequence of the analyzed total metal concentration found in our result is almost similar with the order of metal concentration $(\mathrm{Fe}>\mathrm{Mn}>\mathrm{Zn}>\mathrm{Ni}>\mathrm{Cu}>$ $\mathrm{Pb}>\mathrm{Cr}>\mathrm{Cd}>\mathrm{Hg}$ ) analyzed by Harikumar et al. [32] for different tropical aquatic plant species.

With few exceptions the concentrations of metals were above the standard set for aquatic macrophytes by WHO [12] and Frances [13]. Moreover, the examined sediment can be considered slightly polluted with the analyzed metal elements, since their concentrations were out of the typical range concentrations found in soils/sediment under fresh water bodies $[8,31]$. This suggests that metal contents in the lake sediments are largely associated with industries, and floriculture and city sewage. According to MacDonald et al. [14] and Perin et al. [41] sediment in Hawassa Lake was moderately polluted by $\mathrm{Zn}$ particularly at $S_{4}$ and non-polluted by the rest of the metals at all sites. Therefore, the present study shows that bio monitoring should be taken in order to prevent further metal pollution. Generally, there are potential sources of pollutants to the lake from various directions particularly from the northern side of the lake. Agro industrial activities around $\mathrm{S}_{1}$ and $\mathrm{S}_{2}$ might be the most potent pollutant sources as compare to other sites. Industrial effluents and non-point pollution sources as well as changes in atmospheric precipitation can lead to local increase in 
Citation: Amare TA, Yimer GT, Workagegn KB (2014) Assessment of Metals Concentration in Water, Sediment and Macrophyte Plant Collected from Lake Hawassa, Ethiopia. J Environ Anal Toxicol 4: 247. doi: 10.4172/2161-0525.1000247

Page 6 of 7

metal concentration of water. In addition, total metal concentration in aquatic ecosystem can reflect the present pollution status of these areas [42].

\section{Conclusion and Recommendation}

As compared to $\mathrm{S}_{6}$ (reference site), all sampling sites have higher metals concentration for all the three media: water, sediment and plant samples. Although all sampling sites showed the presence of all the five metals analyzed $(\mathrm{Zn}, \mathrm{Cr}, \mathrm{Pb}, \mathrm{Cd}$, and $\mathrm{Hg})$, the concentration in sediment and macrophyte samples at $\mathrm{S}_{2}, \mathrm{~S}_{4}$ and $\mathrm{S}_{5}$ have higher than metals concentration at $S_{1}$ and $S_{3}$. Metals concentration in most sites followed the order of sediment $>S$. corymbosus $>$ water. According to international standards based on numerical sediment quality guidelines (SQGs) sediment of Lake Hawassa are generally non-polluted to moderately polluted range. All these are an early signal to take timely measure to maintain the present quality of the lake. Therefore, strategy to control point and non-point sources of all over the shorelines should be developed for better protection of the lake as well as the surrounding catchment areas.

\section{Acknowledgment}

The authors would like to thank Ethiopian EPA Staff found at Addis Ababa for their cooperating and facilitating the laboratory analyses, the NUFU project for funding this research. The authors also like to thanks the NUFU project coordinator Dr Elias Dadebo and Dr. Tesfaye Abebe for their facilitating the research facilities during this studying.

\section{References}

Zinabu Gebre-Mariam (2002) The Ethiopian Rift Valley Lakes: major threats and strategies for conservation. In: Biology of Inland Water Series, Ethiopian Rift Valley Lakes, (Tudorancea, C and Taylor, W.D. ed.). Backhuy publishers, Leiden, The Netherlands 259-271.

1. Zerihun Desta (1997) Industrial environmental management: the case of Hawassa textile factory, Ethiopia. M.Sc. thesis Wageningen Agricultural University. The Netherlands, 95.

2. Walker C, Hopkin S, Sibly R, Peakall D (2006) Principles of ecotoxicology, CRC press: Taylor and Francis Group, LLc, London, New York.

3. Zinabu Gebre-Mariam (1988) Dynamics of heterotrophic bacterioplankton in an Ethiopian rift-valley lake (Hawassa). PhD Thesis. University of Waterloo, Ontario, Canada, 180

4. Elizabeth K, Amha B (1994) Species composition and phytoplankton biomass in a tropical African lake (Lake Awassa, Ethiopia). Hydrobiologia 288: 13-32.

5. Seyoum Mengstu, Fernando $\mathrm{CH}$ (1991) Seasonality and abundance of some dominant crustacean zooplankton in Lake Awassa, a tropical rift valley lake in Ethiopia. Hydrobiologia 226: 137-152.

6. Demeke Admassu, Elias Dadebo (1997) Diet composition, length-weigh relationship and condition factor of Labeobarbus species (Pisces: Cyprinidae) in Lake Awassa, Ethiopia. SINET Ethiop J Sci 20: 83-96.

7. Kabata-Pendias A, Pendias H (1992) Trace Elements in Soils and Plants. 2nd edition. CRC Press, Boca Raton, Fla.

8. USEPA (1991) Compendium of ERT surface water and sediment sampling procedures. Office of solid waste and emergency response directive.

9. USEPA (1999) National recommended water quality criteria-correction-United State Environmental Protection Agency.

10. Bass JAB, Blust R, Clarke RT, Corbin TA, Davison W et al. (2008) Environmenta Quality Standards for trace metals in the aquatic environment. Environmental Agency Rio House Waterside Drive, Aztec West Almonds bury, Bristol.

11. WHO (2008) Guidelines for drinking :- water Quality 3rd. Ed. incorporating the first and second agenda vol 1. World Health Organizations Geneva.

12. Frances $S$ (2008) Impact of metal on aquatic ecosystems and human health Environmental and communities. British, Columbia.

13. MacDonald DD, Ingersoll CG, Berger TA (2000) Development and evaluation of consensus-based sediment quality guidelines for freshwater ecosystems. Arch Environ Contam Toxicol 39: 20-31.

14. Teresa B, Neff $\mathrm{J}(2008)$ Metals Bioavailability in the Navy's Tiered Ecological Risk Assessment Process. Washington DC 1-15.

15. Norusis MJ (1993) SPSS for Windows Professional Statistics 61 SPSS Inc. Chicago.

16. Karpiscak MM, Whiteake LR, Artiola JF, Foster KE (2001) Nutrient and heavy metal uptake and storage in constructed wetland systems in Arizona. Water Sci Technol 44: 455-462.

17. Igbinosa EO, Okoh Al (2009) Impact of discharge wastewater effluents on the phsico-chemical qualities of a receiving water shade in typical rural community. Int J Environ Sci Tech 6: 175-182.

18. Salmasi R, Tavassoli A (2006) Pollution of south of Tehran ground waters with heavy metals. Int J Environ Sci Tech 3: 147-152.

19. Seyoum Leta, Fasil Assefa, Gunnel D (2003) Characterization of Tannary waste water and assessment of downstream pollution profiles along Mojo River in Ethiopia. Ethiop J Biol Sci 2: 157-168.

20. Phiri O, Mumba P, Moyo WZ (2005) Assessment of the impact of industria effluents on water quality of receiving rivers in urban areas of Malawi. Int $J$ Environ Sci Tech 2: 237-244

21. Okafor E, Opuene K (2006) Correlations, partitioning and bioaccumulation of trace metals between different segments of Taylor Creek, southern Nigeria. Int J Environ Sci Tech 3: 381-389.

22. Kar D, Sur P, Mandal SK, Saha T, Kole RK (2008) Assessment of heavy metal pollution in surface water. Int J Environ Sci Tech 5: 119-124.

23. Nirmal KJI, Soni H, Kumar RN, Bhatt I (2008) Macrophytes in phytoremediation of heavy metal contaminated water and sediments in Pariyej community reserve, Gujarat, India J of Fisheries and Aquatic Sci 8: 193-200.

24. Binming K, Baird D (2001) Survey of heavy metals in the sediment of the Swarkops River Estuary. Water Poll SA 27: 461-466.

25. Kumar SP, Edward JKP (2009) Assessment of metal concentration in the sediment cores of Manakudy estuary, south west coastal of India. Indian J Mar Sci 38: 235-248.

26. Awfolu OR, Mbolekwa Z, Mtshemla V, Fatoki OS (2005) Levels of trace metals in water and sediment from Tyume River and its effects on an irrigated farmland, Water Poll SA 31: 87-94

27. Abdel-Satar AM (2008) Chemistry of major ions, nutrient salts and heavy metals in Lake Manzalah Egypt. Egyption J of Aquat Research, 34: 130-148.

28. Siegel F, Slaboda M, Stanely D (1994) Metal pollution loading, Manzalah Lagoon, Egypt: Implications for aquaculture. Environ Geol 23: 89-98.

29. Ramdan AA (2003) Heavy metal pollution and bio monitoring plants in Lake Manzala, Egypt, Pak J Biol Sci 6: 1108-1117.

30. USEPA (1997) Superfund program representative sampling guidance for surface water and sediment, Vol. 5 Washington, DC.

31. Harikumar PS, Nasir UP, Mujeebu RMP (2009) Distribution of heavy metals in the core sediments of a tropical wetland system. Int J Environ Sci Tech 6: 225-232.

32. Abdo MH, El-Nasharty SM (2010) Physico-chemical evaluations and trace metals distribution in water and sediment of Ismailia Canal, Egypt. Nature and Sciences 8: 198-206.

33. Freedman B (1990) Toxic elemental ecology. Academic press.

34. Sekabira K, Oryem-Origa H, Basamba TA, Mutumba G, Kakudidi E (2010) . Int J Environ Sci Tech 7: 759-770.

35. Nabizadeh R, Mahvi A, Mardani G, Yunesian M (2005) Study of heavy metals in urban runoff. Int J Environ Sci Tech1: 325-333.

36. Flathman PE, Lanza GR (1998) Phytoremediation: current views on an emerging green technology. J of Soil Cont 7: 415-432.

37. Jones R, Chambers FM, Benson-Evans K (1991) Heavy metals ( $\mathrm{Cu}$ and $\mathrm{Zn}$ ) in recent sediments of llangrose Lake. Hydrobiol 214: 149-154.

38. Reza R, Singh G (2010) Heavy metal contamination and its indexing approach for river water. Int J Environ Sci Tech 7: 785-792. 
Citation: Amare TA, Yimer GT, Workagegn KB (2014) Assessment of Metals Concentration in Water, Sediment and Macrophyte Plant Collected from Lake Hawassa, Ethiopia. J Environ Anal Toxicol 4: 247. doi: 10.4172/2161-0525.1000247

Page 7 of 7

39. Doust JL, Schmidt M, Doust LL (1994) Biological assessment of aquatic pollution: a review, with emphasis on plants as biomonitors. Biol Rev Camb Philos Soc 69: 147-186.

40. Perin G, Bonardi M, Fabris R, Simoncini B, Manente S et al. (1997) Heavy metal pollution in central Venice Lagoon bottom sediments: evaluation of the metal bioavailability by geochemical speciation procedure. Environ Tech 18 : 593-604.

41. Haiyan W, Stuane AO (2003) Heavy metal pollution in air-water-soil-plant system of Zhuzhou City, Human Province, China. Water, Air and Soil Pollution 147: $79-107$ 